\title{
Follicular Fluid from Infertile Women with Mild Endometriosis Impairs In Vitro Bovine Embryo Development: Potential Role of Oxidative Stress
}

\section{Fluido folicular de mulheres inférteis com endometriose leve prejudica o desenvolvimento in vitro de embriões bovinos: Potencial papel do estresse oxidativo}

\author{
Vanessa Silvestre Innocenti Giorgi ${ }^{1}{ }^{10}$ Rui Alberto Ferriani ${ }^{1,2}$ Paula Andrea Navarro ${ }^{1,2}$ (1)
}

${ }^{1}$ Human Reproduction Division, Department of Gynecology and Obstetrics, Faculdade de Medicina de Ribeirão Preto, Universidade de São Paulo, Ribeirão Preto, SP, Brazil

${ }^{2}$ Conselho Nacional de Desenvolvimento Científico e Tecnológico, Brasília, DF, Brazil

Rev Bras Ginecol Obstet 2021;43(2):119-125.
Address for correspondence Vanessa Silvestre Innocenti Giorgi, PhD, Avenida Bandeirantes, 3900, Monte Alegre, Ribeirao Preto, SP, 14049-900, Brazil (e-mail: vanessasig@gmail.com).

\begin{abstract}
Objective To investigate whether follicular fluid (FF) from infertile women with mild endometriosis (ME) alters in vitro bovine embryo development, and whether the antioxidants $\mathrm{N}$-acetyl-cysteine (NAC) and/or L-carnitine (LC) could prevent such damages.

Methods Follicular fluid was obtained from infertile women (11 with ME and 11 control). Bovine oocytes were matured in vitro divided in: No-FF, with $1 \%$ of FF from control women (CFF) or ME women (MEFF); with $1.5 \mathrm{mM}$ NAC (CFF + NAC, $\mathrm{MEFF}+\mathrm{NAC})$, with $0.6 \mathrm{mg} / \mathrm{mL}$ LC $(\mathrm{CFF}+\mathrm{LC}, \mathrm{MEFF}+\mathrm{LC})$, or both antioxidants $(\mathrm{CFF}+\mathrm{NAC}+\mathrm{LC}, \mathrm{MEFF}+\mathrm{NAC}+\mathrm{LC})$. After in vitro fertilization, in vitro embryo culture was performed for 9 days.

Results A total of 883 presumptive zygotes were cultured in vitro. No differences were observed in cleavage rate $(p=0.5376)$ and blastocyst formation rate $(p=0.4249)$. However, the MEFF group (12.5\%) had lower hatching rate than the No-FF $(42.1 \%, p=0.029)$ and CFF $(42.9 \%, p=0.036)$ groups. Addition of antioxidants in

Keywords

- infertility

- endometriosis

- oocyte quality

- N-acetyl-cysteine

- L-carnitine the group with CFF did not alter hatching rate $(p \geq 0.56)$, and in groups with MEFF, just NAC increased the hatching rate [(MEFF: $12.5 \%$ versus MEFF + NAC: $44.4 \%(p=0.02)$; vs MEFF + LC: $18.8 \%(p=0.79)$; versus MEFF + NAC + LC: $30.8 \%(p=0.22)]$.

Conclusion Therefore, $\mathrm{FF}$ from infertile women with ME added to medium of in vitro maturation of bovine oocytes impairs hatching rate, and NAC prevented these damages, suggesting involvement of oxidative stress in worst of oocyte and embryo quality of women with ME.
\end{abstract}

received

March 18, 2020

accepted

August 12, 2020

published online

January 28, 2021
DOI https://doi.org/

$10.1055 / \mathrm{s}-0040-1718443$ ISSN $0100-7203$. (c) 2021. Federação Brasileira das Associações de Ginecologia e Obstetrícia. All rights reserved.

This is an open access article published by Thieme under the terms of the Creative Commons Attribution License, permitting unrestricted use, distribution, and reproduction so long as the original work is properly cited. (https://creativecommons.org/licenses/by/4.0/)

Thieme Revinter Publicações Ltda., Rua do Matoso 170, Rio de Janeiro, RJ, CEP 20270-135, Brazil 


\section{Resumo}

\section{Palavras-chave \\ - infertilidade \\ - endometriose \\ - qualidade oocitária \\ - N-acetil-cisteína \\ - L-carnitina}

Objetivo Investigar se o fluido folicular (FF) de mulheres inférteis com endometriose leve (ME, na sigla em inglês) altera o desenvolvimento in vitro de embriões bovinos, e se os antioxidantes $\mathrm{N}$-acetil-cisteína (NAC) e/ou L-carnitina (LC) poderiam prevenir possíveis danos.

Métodos O FF foi obtido de mulheres inférteis (11 com ME e 11 controles). Oócitos bovinos foram maturados in vitro divididos em: sem FF (No-FF), com 1\% de FF de mulheres controle (CFF) ou mulheres com ME (MEFF); com 1,5 mM de NAC (CFF + NAC, MEFF + NAC), com $0,6 \mathrm{mg} / \mathrm{mL}$ de $\mathrm{LC}(\mathrm{CFF}+\mathrm{LC}$, MEFF $+\mathrm{LC})$, ou ambos antioxidantes $(\mathrm{CFF}+\mathrm{NAC}+\mathrm{LC}, \mathrm{MEFF}+\mathrm{NAC}+\mathrm{LC})$. Depois da fertilização in vitro, o cultivo in vitro de embriões foi realizado por 9 dias.

Resultados Um total de 883 zigotos presumidos foram cultivados in vitro. Nenhuma diferença foi observada na taxa de clivagem $(p=0,5376)$ e na taxa de formação de blastocistos $(p=0,4249)$. Entretanto, o grupo MEFF $(12.5 \%)$ teve menor taxa de eclosão de blastocistos do que os grupos No-FF $(42,1 \%, p=0,029)$ e CFF $(42,9 \%$, $p=0,036$ ). Adição de antioxidantes no grupo com CFF não alterou a taxa de eclosão ( $p$ $\geq 0.56)$, e nos grupos com MEFF, somente a NAC aumentou a taxa de eclosão [(MEFF: $12.5 \%$ versus MEFF + NAC: $44.4 \%(p=0.02)$; versus MEFF $+\mathrm{LC}: 18.8 \%(p=0.79)$; versus MEFF + NAC + LC: $30.8 \%(p=0.22)]$.

Conclusão Portanto, o FF de mulheres inférteis com ME adicionado ao meio de maturação in vitro de oócitos bovinos prejudica a taxa de closão embrionária, e a NAC preveniu esses danos, sugerindo o envolvimento do estresse oxidativo na piora da qualidade oocitária e embrionária de mulheres com ME.

\section{Introduction}

Endometriosis is a benign gynecological disease characterized by the presence and growth of endometrial tissue (glands and stroma) outside the uterus. ${ }^{1}$ This disease is associated with infertility: $\sim 30 \%$ of infertile women present endometriosis $^{2}$ and between 30 and $50 \%$ of women with endometriosis have difficulties in becoming pregnant. ${ }^{3}$

In cases with advanced endometriosis (moderate or severe, stage III/IV), infertility could be due to pelvic anatomical alterations caused by lesions and adherences. ${ }^{4}$ On the other hand, minor endometriosis (minimal or mild, stage $\mathrm{I} / \mathrm{II}$ ) is not associated with marked changes in the pelvic anatomy (American Society for Reproductive Medicine [ASRM], 1997) ${ }^{4}$ It is unclear whether, after assisted reproduction technologies (ART), endometriosis has a negative impact on clinical pregnancy and live birth rates. ${ }^{5-7}$ Findings from the most recent meta-analysis showed that women with and without endometriosis have comparable ART outcomes in terms of live births, whereas those with severe endometriosis have inferior outcomes. ${ }^{6}$ On the other hand, classical studies assessing natural conception reported lower cumulative pregnancy rate in women with early-stage endometriosis compared with women with infertility of unknown cause. ${ }^{8,9}$

In endometriosis women, menstrual reflux and macrophages have been implicated as potential inducers of oxidative stress $(O S)^{10,11}$ which, in turn, is involved in impairment of oocyte quality, and in compromising the reproductive capacity of women with early-stage endometriosis. ${ }^{12,13}$
Previous studies demonstrated that follicular fluid (FF) from infertile women with mild endometriosis (ME), when added during in vitro maturation (IVM) causes chromosome misalignment and meiotic spindle alterations in bovine ${ }^{14,15}$ and murine ${ }^{16}$ oocytes. Alterations in oocytes during IVM may affect in vitro embryo development. ${ }^{17,18}$ However, no study to date has evaluated the effect of FF from infertile women with ME on embryo development and the impact of antioxidants on this response.

L-carnitine (LC) is a lysine derivative that clears hydrogen peroxide and products of lipid peroxidation. ${ }^{19}$ In mitochondria, LC also facilitates the transport of fatty acids during $\beta$ oxidation, a major pathway for Adenosine Triphosphate (ATP) production. ${ }^{20} \mathrm{~N}$-acetyl-cysteine (NAC) is an amino thiol with immunomodulatory, anti-apoptotic, and antioxidant properties. ${ }^{21} \mathrm{~N}$-acetyl-cysteine is a precursor of intracellular cysteine and reduced glutathione (GSH), which also is and intracellular antioxidant. $^{22}$

As human oocytes and embryos are extremely rare, and their use in invasive studies usually prevents their subsequent use in ART, studies using animal models may be useful for the elucidation of the mechanism by which endometriosis leads to infertility. Our hypothesis is that ME leads to OS, and this leads to infertility due to an impairment of oocyte and embryo quality. Therefore, the aim of the present study was to evaluate the impact of adding FF from infertile women with ME and without endometriosis (control), and antioxidants (NAC and/ or LC) to the IVM medium of bovine oocytes on in vitro embryo development (cleavage, blastocyst formation and hatching). 


\section{Methods}

The present experimental study used an in vitro bovine model. The present study was approved by the Ethics Committee for Animal Experimentation of the Faculdade de Medicina de Ribeirão Preto, Universidade de São Paulo (FMRP-USP, in the Portuguese acronym) ( $\left.n^{\circ} 169 / 2008\right)$ and the Research Ethics Committee of the University Hospital, FMRP-USP ( $\left.n^{\circ} 12201 / 2008\right)$.

\section{Patient Selection and Follicular Fluid Collection}

Twenty-two FF samples were obtained between February 2009 and February 2011 from infertile women who underwent ovarian stimulation for intracytoplasmic sperm injection (ICSI) at the Sector of Human Reproduction, Department of Gynecology and Obstetrics of the FMRP-USP.

The endometriosis group consisted of patients with infertility associated exclusively with ME, without other gynecological or clinical conditions. An experienced surgeon diagnosed and classified these women by videolaparoscopy using the criteria of the American Society for Reproductive Medicine (1997). ${ }^{4}$ The control group consisted of women with tubal or male factor infertility. All control women also underwent videolaparoscopy as part of the protocol for investigation of marital infertility. None of the controls had endometriosis or any other gynecological diseases.

The exclusion criteria were established to reduce confounding factors that could affect OS and/or oocyte quality. Thus, women with any of the following conditions were excluded: age $\geq 38$ years old; body mass index (BMI) $\geq$ $30 \mathrm{~kg} / \mathrm{m}^{2}$; serum concentration of follicle stimulating hormone (FSH) on the $3^{\text {rd }}$ day of the menstrual cycle $\geq 10 \mathrm{mIU} /$ $\mathrm{mL}$; chronic anovulation; presence of hydrosalpinx or chronic diseases such as diabetes mellitus or any other endocrinopathy; cardiovascular disease; dyslipidemia; systemic lupus erythematosus or any other rheumatologic disease; HIV infection or any other active infection; smoking; and use of vitamins, hormonal or nonhormonal medications during the 6 months before inclusion in the study.

Comparison of the means and standard errors of the means (SEMs) indicated that the endometriosis and control groups had similar age $(32.72 \pm 0.52$ versus $30.63 \pm 1.36$ years old), FSH concentration on the $3^{\text {rd }}$ day of the menstrual cycle $(5.02 \pm 0.90$ versus $5.79 \pm 0.62 \mathrm{mIU} / \mathrm{mL})$, number of follicles measuring between 14 and $17 \mathrm{~mm}(10.09 \pm 1.43$ versus $6.11 \pm 1.52 \mathrm{~mm}$ ), and number of follicles of at least $18 \mathrm{~mm}$ after ovarian stimulation $(4.89 \pm 0.72$ versus $3.11 \pm 0.76 \mathrm{~mm})$.

\section{Protocol of Controlled Ovarian Stimulation}

Controlled ovarian stimulation (COS) was performed according to our institutional protocol (long protocol). Pituitary blockade was performed by administering an agonist of gonadotropin releasing hormone (GnRH) (Lupron, Abbott, São Paulo, SP, Brazil). Controlled ovarian stimulation was performed by administering recombinant FSH (Gonal-F, Serono, Geneva, Switzerland; Puregon, Organon, Oss, The Netherlands), and ovulation was induced with human chori- onic gonadotropin (hCG) (Ovidrel, EMD Serono, Rockland, MA, USA).

Each patient received a daily subcutaneous injection of $0.5 \mathrm{mg}$ leuprolide acetate (Lupron; Abbott) starting 10 days after the first ultrasound exam before COS. Recombinant FSH (Gonal-F; Puregon, 200-225 units/day) was administered during ovarian stimulation, and follicular growth was monitored. Ovulation was triggered with Ovidrel, and oocytes were retrieved between 34 and 36 hours later.

\section{Collection and Processing of FF Samples}

Follicular fluid was collected into individual sterile tubes preheated to $37^{\circ} \mathrm{C}$ in the absence of culture medium. The sample was only from the first follicle (mean diameter $\geq 15 \mathrm{~mm}$ ) of the first ovary punctured, with aspiration of the full follicular content. Only FF with no blood contamination upon visual inspection and with a mature oocyte was used. The samples were centrifuged at $300 \mathrm{~g}$ for 10 minutes to remove the remaining cells, and the supernatant was stored at $-80^{\circ} \mathrm{C}$ in two aliquots for future use. Follicular fluid was collected from 22 infertile women, 11 with ME and 11 with male and/or tubal infertility.

We pooled the $11 \mathrm{FF}$ samples of each group for experiments because we had previously tested these samples individually in a study of the role of FF from women with infertility related to ME. ${ }^{14}$ The results of that study indicated no intragroup differences and a homogeneous response in all 11 samples from each group. This previous study ${ }^{14}$ also tested the effect of 4 different FF concentrations added to the IVM medium ( $1 \%, 5 \%, 10 \%$, and $15 \%)$ and indicated no dose-dependent effect. Thus, we used 1\% FF concentration.

\section{Chemicals and Reagents}

All chemicals and reagents were purchased from Sigma Chemical Co (St. Louis, MO, USA), unless otherwise stated.

\section{Preparation of Antioxidant (N-acetyl-cysteine and L-carnitine) Solutions}

The solutions of both anti-oxidants were prepared at $100 \times(150 \mathrm{mM}$ NAC and $60 \mathrm{mg} / \mathrm{mL} \mathrm{LC})$ using water after passage through a filter with $0.22 \mu \mathrm{m}$ pore. The NAC concentration used to supplement the IVM was $1.5 \mathrm{mM},{ }^{23}$ and the LC concentration was $0.6 \mathrm{mg} / \mathrm{mL}^{18}$

\section{Oocyte Collection}

Bovine ovaries were collected immediately after slaughter and transported in physiological saline maintained at between 35 and $38.5^{\circ} \mathrm{C}$. In the laboratory, the ovaries were washed with physiological saline supplemented with an antibiotic, and follicles measuring 2 to $8 \mathrm{~mm}$ were aspirated by a 21 -gauge needle mounted on a $10-\mathrm{mL}$ syringe. Cumulusoocyte complexes (COCs), with homogeneous cytoplasm and at least 4 layers of cumulus oophorus cells, corresponding to grades 1 and 2 as described previously, ${ }^{24}$ were selected under a stereomicroscope and washed in holding medium (TCM-199 medium containing Hanks salts, HEPES buffer, and L-glutamine (Invitrogen, Gibco Laboratories Life Technologies, Thermo Fisher Scientific, Waltham, MA, USA). 


\section{In Vitro Maturation}

Selected COCs were cultured in plates containing 4 wells (NUNC, Thermo Fisher Scientific, Waltham, MA, USA) in groups of 20 per well, with $400 \mu \mathrm{L}$ of culture medium for IVM at $38.5^{\circ} \mathrm{C}$, $95 \%$ humidity, and $5 \% \mathrm{CO}_{2}{ }^{17,25}$ in a culture system without mineral oil for between 22 and 24 hours. The IVM medium was TCM-199 with Earle salts and bicarbonate (Invitrogen, Gibco Laboratories Life Technologies, Thermo Fisher Scientific, Waltham, MA, USA) supplemented with $0.4 \mathrm{mM}$ sodium pyruvate, $0.5 \mu \mathrm{g} / \mathrm{mL}$ gentamicin, $5 \mu \mathrm{g} / \mathrm{mL}$ FSH, $5 \mathrm{mg} / \mathrm{mL} \mathrm{LH}, 1 \mu \mathrm{g} / \mathrm{mL}$ estradiol, and $10 \%$ fetal calf serum (FCS) (Gibco Laboratories Life Technologies, Thermo Fisher Scientific, Waltham, MA, USA)

\section{In Vitro Fertilization}

In vitro matured oocytes were fertilized in vitro with frozen semen from a single bull (CRV Lagoa, SP, Brazil). Before addition, the frozen semen was thawed in $35^{\circ} \mathrm{C}$ water for $30 \mathrm{sec}-$ onds. Swim-up was realized as described by Parrish et al. ${ }^{26,27}$

Briefly, the COCs were gently pipetted to remove adhering granulosa cells and to break apart aggregations. The disaggregated COCs were transferred into $50 \mu \mathrm{L}$ microdrops of fertilization medium $(114 \mathrm{mM} \mathrm{NaCl}, 3.1 \mathrm{mM} \mathrm{KCl}, 25 \mathrm{mM}$ NaHCO3, 47 mg/L NaH2PO4.H2O, 10 mM HEPES, 10 mM sodium lactate $60 \%, 1.4 \mathrm{mM}$ caffeine, $0.5 \mathrm{mM} \mathrm{MgCl} 2.6 \mathrm{H} 2 \mathrm{O}$, $2 \mathrm{mM} \mathrm{CaCl} 2.2 \mathrm{H} 2 \mathrm{O}, 0.4 \mathrm{mM}$ sodium pyruvate, $0.5 \mu \mathrm{g} / \mathrm{mL}$ gentamicin, $6 \mathrm{~g} / \mathrm{L} \mathrm{BSA}, 10 \mu \mathrm{g} / \mathrm{mL}$ heparin, and $40 \mu \mathrm{L} / \mathrm{mL}$ each of penicillamine, hypotaurine, and epinephrine). Sperm $(1 \times 106 / \mathrm{mL})$ was added and the medium was maintained for between 18 and 22 hours at $38.5^{\circ} \mathrm{C}$ in a humidified incubator in air with $5 \% \mathrm{CO} 2$.

\section{In Vitro Embryo Culture}

The presumptive zygotes were denuded from cumulus cells by gentle pipetting and cultured in $50 \mu \mathrm{L}$ droplets in CR2aa medium supplemented with $1 \mathrm{mg} / \mathrm{mL}$ BSA, $40 \mu \mathrm{g} / \mathrm{mL}$ sodium pyruvate, $5 \mathrm{mg} / \mathrm{mL}$ hemi-calcium, $20 \mu \mathrm{L} / \mathrm{mL}$ amino acid solution $(0.09 \mu \mathrm{g} / \mathrm{mL}$ glutamine, $0.15 \mu \mathrm{g} / \mathrm{mL}$ alanine, and $0.75 \mu \mathrm{g} / \mathrm{mL}$ glycine), $20 \mu \mathrm{L} / \mathrm{mL}$ Eagle Basal Medium (EBM), $10 \mu \mathrm{L} / \mathrm{mL}$ Eagle Minimum Essential Medium (MEM) and 5\% FBS, at $38.5^{\circ} \mathrm{C}$ in a humidified incubator in air with $5 \% \mathrm{CO} 2$. The culture was maintained for 9 days after fertilization and the medium was renewed every 2 days.

The number of cleaved embryos was recorded on day 3 (72 hours after insemination [HAIs]), blastocyst production was counted on day 7 (168 HAIs), and hatching of blastocysts was checked on day 9 (216 HAIs).

\section{Experimental Design}

Immediately after selection, the COCs were subjected to IVM for between 22 and 24 hours, and divided in groups according to the supplementation of IVM medium with FF and antioxidants according to - Figure 1 (-Fig. 1). After between 22 and 24 hours of IVM, IVF was performed as described above, and embryos were cultured in vitro to assay cleavage, blastocyst formation, and hatching rates.

\section{Statistical Analysis}

Data were analyzed using RStudio software (R Foundation, Vienna, Austria). Categorical variables (cleavage, blastocyst formation and hatching) were expressed as percentage and they were compared by the chi-squared test, considering $p<0.05$.

\begin{tabular}{|c|c|c|c|c|}
\hline & $\begin{array}{l}1 \% \text { Follicular } \\
\text { fluid from } \\
\text { control } \\
\text { patients }\end{array}$ & $\begin{array}{l}1 \% \text { Follicular } \\
\text { fluid from mild } \\
\text { endometriosis } \\
\text { patients }\end{array}$ & $\begin{array}{l}1.5 \mathrm{mM} \text { of } \\
\mathrm{N} \text {-acetyl- } \\
\text { cysteine } \\
\text { (NAC) }\end{array}$ & $\begin{array}{c}0.6 \mathrm{mg} / \mathrm{mL} \\
\text { of } \\
\text { L-carnitine } \\
\text { (LC) }\end{array}$ \\
\hline \multicolumn{5}{|l|}{ No-FF } \\
\hline CFF & $x$ & & & \\
\hline CFF+NAC & $\mathrm{x}$ & & $x$ & \\
\hline CFF+LC & $x$ & & & $x$ \\
\hline CFF+NAC+LC & $x$ & & $x$ & $x$ \\
\hline MEFF & & $x$ & & \\
\hline MEFF+NAC & & $x$ & $x$ & \\
\hline MEFF+LC & & $x$ & & $x$ \\
\hline$M E F F+N A C+L C$ & & $x$ & $x$ & $x$ \\
\hline
\end{tabular}

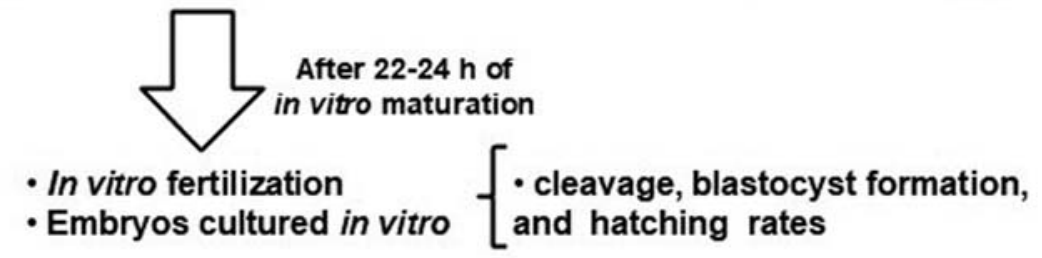

Fig. 1 Experimental design. 


\section{Results}

We performed IVF on 898 mature COCs and then cultured 883 presumptive zygotes in vitro. - Table 1 shows preimplantation embryo development as cleavage rate, blastocyst formation rate and hatching rate of the different groups.

No differences were observed between groups in cleavage $(p=0.5376)$ and blastocysts formation $(p=0.4249)$ rates (-Table 1).

However, in relation to the hatching rate, the groups without FF (No-FF: 42.10\%) and with FF from control women (CFF: 42.86\%) had a higher hatching rate than the group with FF from ME women (MEFF: $12.50 \%$, versus No-FF: $p=0.029$; versus CFF: $p=0.036$ ).

Addition of antioxidants in groups with FF from control women did not alter the hatching rate [CFF versus CFF + NAC (50.0\%, $p=0.800)$, versus CFF $+\mathrm{LC}(32.35 \%, p=0.557)$ and versus CFF + NAC + LC $(39.40 \%, p=0.990)]$.

Addition of NAC in groups with FF from ME women increased hatching rate (MEFF versus MEFF + NAC: $p=0.020$ ), being more efficient than the addition of LC (MEFF + NAC versus MEFF + LC: $p=0.045)$. However, addition of LC and NAC + LC did not alter the hatching rate in groups with FF from ME women (MEFF versus MEFF + LC [18.75\%, $p=0.793]$ and versus MEFF + NAC + LC [30.77\%, $p=0.224]$ ).

Hatching rates in the group with $\mathrm{FF}$ from ME women plus the addition of LC or LC + NAC were similar to the groups without FF (No-FF versus MEFF $+\mathrm{LC}: p=0.066$ and versus MEFF + NAC + LC: $p=0.511)$ and with FF from control women (CFF versus MEFF + LC: $p=0.080$ and versus $\mathrm{MEFF}+\mathrm{NAC}+\mathrm{LC}: p=0.524)$.

\section{Discussion}

The etiopathogenesis of ME-related infertility remains unclear. The present study is the first to show that FF from infertile women with ME impairs bovine embryo development. Besides that, we observed that addition of NAC during IVM can prevent the compromised hatching rate promoted by MEFF.

We observed that FF from ME women added to IVM medium of bovine oocytes did not alter cleavage and blastocyst formation rates, but decreased hatching rate. We expected to find impairment of cleavage in the group with MEFF due to damages on the meiotic spindle of oocytes. ${ }^{14,15,28}$ In vivo, cleavage occurs during embryo transit between the oviduct and the uterus, and many factors can potentially interfere with this process. ${ }^{29}$ A study using time-lapse showed that meiotic spindle visualization of oocytes is not related to the morphokinetic of in vitro embryo development, but it could be related to clinical pregnancy and live births in women with polycystic ovarian syndrome. ${ }^{30}$ A recent study, assessing the impact of endometriosis on embryo development and quality after ICSI, showed similar cleavage rates in groups of women with and without endometriosis, concordant with our findings. ${ }^{31}$ In another recent study, Sanchez et al. ${ }^{31}$ did not find differences in the blastocyst formation rate comparing control and endometriosis groups undergoing ART. Thus, we hypothesize that mild endometriosis may compromise oocyte quality, ${ }^{14,15,32}$ without interfering with cleavage and blastocyst rates, but reducing hatching rate, which could explain lower natural fertility in some of these women. ${ }^{8,9}$

Corroborating our findings, Piromlertamorn et al. ${ }^{33}$ assessed the impact of incubation of mouse oocytes with endometriotic fluid on early embryo in vitro development, and they also did not show differences in cleavage and blastocyst formation, but they observed that endometriotic fluid impaired the hatching rate. $^{33}$ Interestingly, a randomized clinical trial ${ }^{34}$ assessing assisted hatching in embryos from women with endometriosis reported higher implantation and clinical pregnancy rates in the group of women whose embryos had undergone laser-assisted hatching after ICSI, suggesting that compromised hatching rate may be involved in lower implantation rates in women with

Table 1 Embryo development after in vitro fertilization of bovine oocytes which underwent in vitro maturation in medium without follicular fluid (No-FF), with 1\% FF from infertile control women (CFF), or with 1\% FF from infertile women with mild endometriosis (MEFF). The media with CFF and MEFF were supplemented with no antioxidants, $1.5 \mathrm{mM} \mathrm{N}$-acetyl cysteine (NAC), $0.6 \mathrm{mg} / \mathrm{mL} \mathrm{L}$-carnitine $(\mathrm{LC})$, or both antioxidants (NAC+LC)

\begin{tabular}{|c|c|c|c|c|c|c|c|c|c|c|}
\hline & No-FF & CFF & $\mathrm{CFF}+\mathrm{NAC}$ & $\mathrm{CFF}+\mathrm{LC}$ & $\mathrm{CFF}+\mathrm{NAC}+\mathrm{LC}$ & MEFF & $\mathrm{MEFF}+\mathrm{NAC}$ & MEFF+LC & $\mathrm{MEFF}+\mathrm{NAC}+\mathrm{LC}$ & $p$-value \\
\hline $\begin{array}{l}\text { Presumptive } \\
\text { zygotes }(n)\end{array}$ & 100 & 96 & 98 & 98 & 101 & 93 & 97 & 100 & 100 & \\
\hline $\begin{array}{l}\text { Cleavage } \\
\text { rate \% (n) }\end{array}$ & $65.00 \%(65)$ & $61.46 \%$ (59) & $\begin{array}{l}57.14 \% \\
(56)\end{array}$ & $\begin{array}{l}56.12 \% \\
(55)\end{array}$ & $\begin{array}{l}60.40 \% \\
(61)\end{array}$ & $\begin{array}{l}50.54 \% \\
(47)\end{array}$ & $\begin{array}{l}57.73 \% \\
(56)\end{array}$ & $\begin{array}{l}56.00 \% \\
(56)\end{array}$ & $\begin{array}{l}51.00 \% \\
(51)\end{array}$ & $p=0.5376$ \\
\hline $\begin{array}{l}\text { Blastocysts } \\
\text { formation } \\
\text { rate } \%(n)\end{array}$ & $\begin{array}{l}38.00 \% \\
(38)\end{array}$ & $\begin{array}{l}29.17 \% \\
(28)\end{array}$ & $\begin{array}{l}26.53 \% \\
(26)\end{array}$ & $\begin{array}{l}34.69 \% \\
(34)\end{array}$ & $\begin{array}{l}32.67 \% \\
(33)\end{array}$ & $\begin{array}{l}25.81 \% \\
(24)\end{array}$ & $\begin{array}{l}37.11 \% \\
(36)\end{array}$ & $\begin{array}{l}32.00 \% \\
(32)\end{array}$ & $\begin{array}{l}26.00 \% \\
(26)\end{array}$ & $p=0.4249$ \\
\hline $\begin{array}{l}\text { Hatching } \\
\text { rate \% }(n)\end{array}$ & $\begin{array}{l}42.10 \% \\
(16)\end{array}$ & $\begin{array}{l}42.86 \% \\
(12)\end{array}$ & $\begin{array}{l}50.00 \% \\
(13)\end{array}$ & $\begin{array}{l}32.35 \% \\
(11)\end{array}$ & $\begin{array}{l}39.40 \% \\
(13)\end{array}$ & $\begin{array}{l}12.50 \% \\
(3)^{a}\end{array}$ & $\begin{array}{l}44.44 \% \\
(16)\end{array}$ & $\begin{array}{l}18.75 \% \\
(6)^{\mathrm{b}}\end{array}$ & $\begin{array}{l}30.77 \% \\
(8)\end{array}$ & 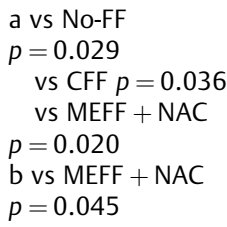 \\
\hline
\end{tabular}

Note: Data were obtained from 5 replicates. Letter indicate $p$ value $<0.05$ (chi-square test).

${ }^{a}$ MEFF vs No-FF $(p=0.029)$, vs CFF $(p=0.036)$, vs MEFF+NAC $(p=0.02)$.

${ }^{\mathrm{b}} \mathrm{MEFF}+\mathrm{LC}$ vs MEFF+NAC $(p=0.045)$. 
endometriosis. A study, assessing embryo quality and implantation rate in infertile women undergoing ART, showed no differences in the number of good quality embryos between women with and without endometriosis, but reported a statistically significant decrease in implantation rate in the endometriosis group. ${ }^{35}$ So, we question whether our findings could explain, at least in part, implantation failure in women with endometriosis and repeated implantation failure after IVF and embryo transfer, which needs further investigation.

Hatching is a prerequisite for embryo implantation in the endometrium and depends on continuous expansion of the blastocele and thinning and rupture of the zona pellucida. ${ }^{36}$ Goud et al. ${ }^{37}$ reported a correlation between follicular levels of nitrate (an oxidative end product of nitric oxide) and zona pellucida dissolution time (an indirect marker of thickness of the zona pellucida) of oocytes from a group of women with endometriosis. So, we hypothesize that FF from women with $\mathrm{ME}$, due to OS, may cause alterations on the zona pellucida of the oocyte, ${ }^{38}$ which compromises the normal hatching processes.

In relation to the addition of antioxidants, NAC and/or LC did not alter cleavage and blastocyst rates in groups with FF from ME women and only NAC prevented reduced blastocyst hatching rates. Thus, we hypothesize that NAC supplementation prevented OS damages in meiotic spindle and on zona pellucida. $\mathrm{N}$-acetyl-cysteine may also have reduced the disulfide bonds in the zona pellucida and induced expansion of the zona pellucida $^{39}$ culminating in hatching. However, a study using a rat model demonstrated that intravenous NAC in high concentration (1000 mg.kg-1/day) promotes infertility probably due to an exacerbated thinning of the zona pellucida. ${ }^{40}$ Thereby, further studies using animal models are needed to evaluate the effect of different concentrations of NAC to determine its efficacy and safety for embryos before its effects can be evaluated in infertile women with endometriosis.

Interestingly, but corroborating our previous study, ${ }^{15}$ concomitant addition of NAC and LC had equal or inferior results relative to NAC or LC alone. We can propose one hypothesis to explain this finding: an interaction of the reactive portions of NAC and LC may have occurred when these antioxidants were solubilized together in aqueous medium, thereby reducing the efficacy of the clearance of free radicals.

Using bovine oocytes and FF from ME women, we aimed to mimetize what could happen in the follicular microenvironment of women with mild endometriosis in natural cycles. However, data obtained from studies using animal models cannot necessarily be extrapolated to humans, and studies evaluating in vitro development of embryos from ME women undergoing ART would be important to confirm our findings. On the other hand, it is important to state that FF obtained from stimulated cycles not necessarily can represent $F F$ from a natural cycle, which needs further investigation.

Therefore, FF from infertile women with ME added to the medium of IVM of bovine oocytes did not interfere with cleavage and blastocyst rates, but impaired hatching rate. $\mathrm{N}$ acetyl-cysteine prevented these damages, suggesting involvement of OS in the worst of oocyte and embryo quality of women with ME. Further studies evaluating the potential clinical application of our findings are needed, especially in terms of improving natural fertility and/or implantation rates in ME women with recurrent implantation failure.

Conflict of Interests

The authors have no conflict of interests to declare.

\section{Contributions}

Giorgi V.S.I.: Data collection, Data analysis, Manuscript writing/editing. Ferriani R.A.: Manuscript writing/editing. Navarro P.A.: Project development, Data analysis, Manuscript writing/editing.

\section{Acknowledgments}

The authors thank the staff of the Human Reproduction Laboratory, University Hospital, Department of Gynecology and Obstetrics at FMRP-USP, especially the embryologists Maria Cristina Picinato and Roberta Cristina Giorgenon for the collection of follicular fluid, and Suleimy Mazin for the statistical analysis. The present work was supported by the Foundation for Research Support of the State of Sao Paulo (Fundação de Amparo à Pesquisa do Estado de São Paulo FAPESP, grant number 2012/15070-1, Brazil) and Foundation for Support of Education, Research and Service of the Hospital of Ribeirao Preto Medical School, University of Sao Paulo (FAEPA).

\section{References}

1 Burney RO, Giudice LC. Pathogenesis and pathophysiology of endometriosis. Fertil Steril. 2012;98(03):511-519. Doi: 10.1016/j.fertnstert.2012.06.029

2 Augoulea A, Alexandrou A, Creatsa M, Vrachnis N, Lambrinoudaki I. Pathogenesis of endometriosis: the role of genetics, inflammation and oxidative stress. Arch Gynecol Obstet. 2012;286(01): 99-103. Doi: 10.1007/s00404-012-2357-8

3 Bulletti C, Coccia ME, Battistoni S, Borini A. Endometriosis and infertility. J Assist Reprod Genet. 2010;27(08):441-447. Doi: 10.1007/s10815-010-9436-1

4 Revised American Society for Reproductive Medicine classification of endometriosis: 1996. Fertil Steril. 1997;67(05):817-821. Doi: 10.1016/s0015-0282(97)81391-x

5 Barbosa MA, Teixeira DM, Navarro PAAS, Ferriani RA, Nastri CO, Martins WP. Impact of endometriosis and its staging on assisted reproduction outcome: systematic review and meta-analysis. Ultrasound Obstet Gynecol. 2014;44(03):261-278. Doi: 10.1002/uog.13366

6 Hamdan M, Omar SZ, Dunselman G, Cheong Y. Influence of endometriosis on assisted reproductive technology outcomes: a systematic review and meta-analysis. Obstet Gynecol. 2015;125 (01):79-88. Doi: 10.1097/AOG.0000000000000592

7 Rossi AC, Prefumo F. The effects of surgery for endometriosis on pregnancy outcomes following in vitro fertilization and embryo transfer: a systematic review and meta-analysis. Arch Gynecol Obstet. 2016;294(03):647-655. Doi: 10.1007/s00404-016-4136-4

8 Bérubé S, Marcoux S, Langevin M, Maheux R; The Canadian Collaborative Group on Endometriosis. Fecundity of infertile women with minimal or mild endometriosis and women with unexplained infertility. Fertil Steril. 1998;69(06):1034-1041. Doi: 10.1016/s0015-0282(98)00081-8

9 Akande VA, Hunt LP, Cahill DJ, Jenkins JM. Differences in time to natural conception between women with unexplained infertility and infertile women with minor endometriosis. Hum Reprod. 2004;19(01):96-103. Doi: 10.1093/humrep/deh045

10 Donnez J, Binda MM, Donnez O, Dolmans MM. Oxidative stress in the pelvic cavity and its role in the pathogenesis of endometriosis. 
Fertil Steril. 2016;106(05):1011-1017. Doi: 10.1016/j.fertnstert.2016.07.1075

11 Samimi M, Pourhanifeh MH, Mehdizadehkashi A, Eftekhar T, Asemi $Z$. The role of inflammation, oxidative stress, angiogenesis, and apoptosis in the pathophysiology of endometriosis: Basic science and new insights based on gene expression. J Cell Physiol. 2019;234(11):19384-19392. Doi: 10.1002/jcp.28666

12 Da Broi MG, Navarro PA. Oxidative stress and oocyte quality: ethiopathogenic mechanisms of minimal/mild endometriosisrelated infertility. Cell Tissue Res. 2016;364(01):1-7. Doi: 10.1007/s00441-015-2339-9

13 Da Broi MG, Jordão AA Jr, Ferriani RA, Navarro PA. Oocyte oxidative DNA damage may be involved in minimal/mild endometriosis-related infertility. Mol Reprod Dev. 2018;85(02): 128-136. Doi: $10.1002 / \mathrm{mrd} .22943$

14 Da Broi MG, Malvezzi H, Paz CC, Ferriani RA, Navarro PA. Follicular fluid from infertile women with mild endometriosis may compromise the meiotic spindles of bovine metaphase II oocytes. Hum Reprod. 2014;29(02):315-323. Doi: 10.1093/humrep/det378

15 Giorgi VS, Da Broi MG, Paz CC, Ferriani RA, Navarro PA. N-acetylcysteine and l-carnitine prevent meiotic oocyte damage induced by follicular fluid from infertile women with mild endometriosis. Reprod Sci. 2016;23(03):342-351. Doi: 10.1177/1933719115602772

16 Romero S, Pella R, Zorrilla I, Berrío P, Escudero F, Pérez Y, et al. Coenzyme Q10 improves the in vitro maturation of oocytes exposed to the intrafollicular environment of patients on fertility treatment. JBRA Assist Reprod. 2020;24(03):283-288. Doi: 10.5935/1518-0557.20200003

17 Adona PR, Lima Verde Leal C. Meiotic inhibition with different cyclin-dependent kinase inhibitors in bovine oocytes and its effects on maturation and embryo development. Zygote. 2004; 12(03):197-204. Doi: 10.1017/s0967199404002771

18 Mansour G, Abdelrazik H, Sharma RK, Radwan E, Falcone T, Agarwal A. L-carnitine supplementation reduces oocyte cytoskeleton damage and embryo apoptosis induced by incubation in peritoneal fluid from patients with endometriosis. Fertil Steril. 2009;91(5, Suppl) 2079-2086. Doi: 10.1016/j.fertnstert.2008.02.097

19 Yazaki T, Hiradate Y, Hoshino Y, Tanemura K, Sato E. L-carnitine improves hydrogen peroxide-induced impairment of nuclear maturation in porcine oocytes. Anim Sci J. 2013;84(05): 395-402. Doi: 10.1111/asj.12016

20 Bremer J, Woldegiorgis G, Schalinske K, Shrago E. Carnitine palmitoyltransferase. Activation by palmitoyl-CoA and inactivation by malonyl-CoA. Biochim Biophys Acta. 1985;833(01):9-16. Doi: 10.1016/0005-2760(85)90247-4

21 Samuni Y, Goldstein S, Dean OM, Berk M. The chemistry and biological activities of N-acetylcysteine. Biochim Biophys Acta. 2013;1830(08):4117-4129. Doi: 10.1016/j.bbagen.2013.04.016

22 Dekhuijzen PN. Antioxidant properties of N-acetylcysteine: their relevance in relation to chronic obstructive pulmonary disease. Eur Respir J. 2004;23(04):629-636. Doi: 10.1183/ 09031936.04.00016804

23 Whitaker BD, Casey SJ, Taupier R. The effects of N-acetyl-Lcysteine supplementation on in vitro porcine oocyte maturation and subsequent fertilisation and embryonic development. Reprod Fertil Dev. 2012;24(08):1048-1054. Doi: 10.1071/RD12002

24 de Loos F, van Vliet C, van Maurik P, Kruip TA. Morphology of immature bovine oocytes. Gamete Res. 1989;24(02):197-204. Doi: $10.1002 / \operatorname{mrd} .1120240207$

25 Ferreira EM, Vireque AA, Adona PR, Ferriani RA, Navarro PA. Prematuration of bovine oocytes with butyrolactone I reversibly arrests meiosis without increasing meiotic abnormalities after in vitro maturation. Eur J Obstet Gynecol Reprod Biol. 2009;145(01): 76-80. Doi: 10.1016/j.ejogrb.2009.03.016
26 Parrish JJ, Susko-Parrish JL, Leibfried-Rutledge ML, Critser ES, Eyestone WH, First NL. Bovine in vitro fertilization with frozenthawed semen. Theriogenology. 1986;25(04):591-600. Doi: 10.1016/0093-691x(86)90143-3

27 Parrish JJ, Susko-Parrish J, Winer MA, First NL. Capacitation of bovine sperm by heparin. Biol Reprod. 1988;38(05):1171-1180. Doi: 10.1095/biolreprod38.5.1171

28 Barcelos ID, Vieira RC, Ferreira EM, Martins WP, Ferriani RA, Navarro PA. Comparative analysis of the spindle and chromosome configurations of in vitro-matured oocytes from patients with endometriosis and from control subjects: a pilot study. Fertil Steril. 2009;92(05):1749-1752. Doi: 10.1016/j.fertnstert.2009.05.006

29 Kawamura K, Chen Y, Shu Y, Cheng Y, Qiao J, Behr B, et al. Promotion of human early embryonic development and blastocyst outgrowth in vitro using autocrine/paracrine growth factors. PLoS One. 2012;7 (11):e49328. Doi: 10.1371/journal.pone.0049328

30 Tabibnejad N, Soleimani M, Aflatoonian A. Zona pellucida birefringence and meiotic spindle visualization are not related to the time-lapse detected embryo morphokinetics in women with polycystic ovarian syndrome. Eur J Obstet Gynecol Reprod Biol. 2018;230:96-102. Doi: 10.1016/j.ejogrb.2018.09.029

31 Sanchez AM, Pagliardini L, Cermisoni GC, Privitera L, Makieva S, Alteri A, et al. Does endometriosis influence the embryo quality and/or development? Insights from a large retrospective matched cohort study. Diagnostics (Basel). 2020;10(02):83. Doi: 10.3390/ diagnostics 10020083

32 Xu B, Guo N, Zhang XM, Shi W, Tong XH, Iqbal F, Liu YS. Oocyte quality is decreased in women with minimal or mild endometriosis. Sci Rep. 2015;5:10779. Doi: 10.1038/srep10779

33 Piromlertamorn W, Saeng-anan U, Vutyavanich T. Effects of ovarian endometriotic fluid exposure on fertilization rate of mouse oocytes and subsequent embryo development. Reprod Biol Endocrinol. 2013;11:4. Doi: 10.1186/1477-7827-11-4

34 Nada AM, El-Noury A, Al-Inany H, Bibars M, Taha T, Salama S, et al. Effect of laser-assisted zona thinning, during assisted reproduction, on pregnancy outcome in women with endometriosis: randomized controlled trial. Arch Gynecol Obstet. 2018;297 (02):521-528. Doi: 10.1007/s00404-017-4604-5

35 Radzinsky VY, Orazov MR, Ivanov II, Khamoshina MB, Kostin IN, Kavteladze EV, Shustova VB. Implantation failures in women with infertility associated endometriosis. Gynecol Endocrinol. 2019;35 (sup1, Suppl 1)27-30. Doi: 10.1080/09513590.2019.1632089

36 Kirkegaard K, Hindkjaer JJ, Ingerslev HJ. Effect of oxygen concentration on human embryo development evaluated by time-lapse monitoring. Fertil Steril. 2013;99(03):738-744.e4. Doi: 10.1016/j. fertnstert.2012.11.028

37 Goud PT, Goud AP, Joshi N, Puscheck E, Diamond MP, Abu-Soud HM. Dynamics of nitric oxide, altered follicular microenvironment, and oocyte quality in women with endometriosis. Fertil Steril. 2014;102 (01):151-159.e5. Doi: 10.1016/j.fertnstert.2014.03.053

38 Bromfield EG, Aitken RJ, Anderson AL, McLaughlin EA, Nixon B. The impact of oxidative stress on chaperone-mediated human sperm-egg interaction. Hum Reprod. 2015;30(11):2597-2613. Doi: 10.1093/humrep/dev214

39 Takeo T, Horikoshi Y, Nakao S, Sakoh K, Ishizuka Y, Tsutsumi A, et al. Cysteine analogs with a free thiol group promote fertilization by reducing disulfide bonds in the zona pellucida of mice. Biol Reprod. 2015;92(04):90. Doi: 10.1095/biolreprod.114.125443

40 Harada M, Kishimoto K, Hagiwara R, Nakashima Y, Kurisu K, Kawaguchi Y. Infertility observed in female rats treated with $\mathrm{N}$ acetyl-L-cysteine: Histopathological examination of ovarian follicles and recovery of fertility. Congenit Anom (Kyoto). 2003;43 (03):168-176. Doi: 10.1111/j.1741-4520.2003.tb01040.x 